\title{
Influence of usage environment from camping cooking utensils on migration of hazardous metals
}

\author{
Jin-hee Lee ${ }^{1,2}$, Ji-Yeon Kim ${ }^{1}$, Ye-Seul Park ${ }^{1}$, Sang-Gyu Park ${ }^{1}$, Jae-Ho Lee ${ }^{1}$, \\ Jong-Ho Yoon ${ }^{1}$, Gyung-Tae Kim¹, Gi-Dong Han ${ }^{2 *}$ \\ ${ }^{1}$ Department of Pharmaceutical Chemicals, Daegu Metropolitan City Institute of Health and Environment, Deagu 42183, Korea \\ ${ }^{2}$ Department of Food Science and Technology College of Life Applied Science, Yeungnam University, Gyeongsan 38541, Korea
}

\section{사용 환경에 따른 캠핑용 조리 기구로부터 유해금속 용출의 변화}

\author{
이진희 ${ }^{1,2} \cdot$ 김지연 $^{1} \cdot$ 박예슬 $^{1} \cdot$ 박상규 $^{1} \cdot$ 이재호 $^{1} \cdot$ 윤종호 $^{1} \cdot$ 김경태 $^{1} \cdot$ 한기동 $^{2 *}$ \\ ${ }^{1}$ 대구광역시 보건환경연구원 약품화학과, ${ }^{2}$ 영남대학교 생명응용과학대학 식품공학과
}

\begin{abstract}
Hazardous metals leaching experiment was carried out in accordance with various usage environments for camping cooking utensils distributed in the market. There was a significant difference in the degree of migration for lead, arsenic, cadmium and nickel defending on the solvent and how to use, although they were all appropriate for criteria. In general, the migrated amount of aluminum was increased in acidic condition, and the migrated amount of arsenic was increased in salty condition. Physical scratches increased the overall release of hazardous metals from the portable pots and pans for camping in all solvents. Especially, in $\mathbf{0 . 5 \%}$ citric acid solution, cadmium was migrated by physical scratch in stainless steel and hard aluminum pots and pans. The longer the leaching time, the higher the migration of aluminum in acid condition and arsenic in basic condition. From these results, it is desirable to use the cooking utensil for camping without being exposed to strong acidic or basic solution and scratches in order to reduce the migration of hazardous metals from them.
\end{abstract}

Key words : hazardous metal, cooking utensil, ICP-OES

\section{서 론}

국내 캠핑 시장은 2003년부터 10년 넘게 양적 성장을 지속했다. 소득 수준의 향상과 주 5일제 도입에 따른 여가 시간의 증가에 따라, 도심 속 단조로운 생활을 벗어나 아름 다운 자연과 함께 즐기려는 캠핑 인구의 증가는 시장의 성장을 이끌었다. 통계청에 따르면, 캠핑 인구는 2011년 60만 명에서 2014년에 300만 명을 넘은 것으로 조사되었으 며, 국내외 캠핑 관련 브랜드도 넘쳐나고 있다. 캠핑용 조리 기구는 크게 코펠, 그릴, 석쇠로 구분되어지며, 코펠은 금속

*Corresponding author. E-mail : gdhan1@ynu.ac.kr Phone : 82-53-810-2957, Fax : 82-53-810-4662

Received 19 October 2017; Revised 6 December 2017; Accepted 7 December 2017.

Copyright (c) The Korean Society of Food Preservation. All rights reserved.
제 냄비들과 팬 그리고 식기들로 구성되어 있다. 금속제 냄비는 스테인레스, 알루미늄, 티타늄 재질 제품이 주를 이루고, 팬의 경우는 불소수지 제품이 주로 많다(1).

조리 기구는 요리하는 동안 음식과 지속적으로 접촉되기 때문에 안전성에 대한 소비자의 관심이 증가되고 있는데, 특히 금속제 조리 기구는 구입 후 장기간 사용된다는 점에 서 유해금속과 같은 물질이 조리 과정에서 2차로 오염될 수 있어서 그 중요성이 더욱 크다.

용출되는 유해 금속의 특성을 살펴보면, 납은 인체의 거 의 모든 조직과 시스템에 영향을 미치고 인체에 축적되는 독성 유해 금속이다. 음식물과 공기 등을 통해 체내로 흡수 되며 인체에는 약 $120 \mathrm{mg}$ 의 납이 있는데, 혈액에 $0.2 \mathrm{mg} / \mathrm{kg}$, 뼈에 3-30 mg/kg, 조직에 $0.2-3.0 \mathrm{mg} / \mathrm{kg}$ 농도로 들어있다. 납 중독의 전형적인 증상은 두통, 복통, 구토, 빈혈, 경련, 혼수, 만성 신장염, 중추 신경계 장애 등인데, 높은 농도의 납에 중독되면 성인이나 어린이 모두 뇌와 신장이 손상되어 
사망할 수도 있다. 임산부는 유산을 할 수 있으며, 남성의 생식 기능도 저하 된다. 비소와 대부분의 비소 화합물들은 동물들에 강한 독성을 보이고, 일부는 발암 물질로 알려져 있다. $\mathrm{As}_{2} \mathrm{O}_{3}$ 는 의약품으로 사용되기도 하지만 1 급 발암 물 질이며, 쥐에 대한 치사량은 체중 $1 \mathrm{~kg}$ 당 $14.6 \mathrm{mg}$ 이다. 적은 복용량으로는 메스꺼움, 구토, 설사를 일으키고, 많이 복용하게 되면 심장 박동 이상, 혈관 손상, 심한 통증을 일으켜 죽음에 이를 수도 있다. 비소가 들어있는 공기를 장기간 들이 마시면 폐암에 걸릴 수 있으며, 비소로 오염된 물이나 식품을 장기간 섭취하면 방광암, 피부암, 간암, 신장 암, 폐암 등에 걸릴 수 있다. 카드뮴은 아주 독성이 강하고 생체 내에 축적되어 여러 중독 증상을 일으킨다. 카드뮴은 어패류, 동물의 신장이나 간 등 일부 식품이나 오염된 물을 통해 인체 내로 들어오고, 간과 신장(콩팥)에 축적되어 이들 기관의 손상을 초래한다. 특히 신장 손상은 인체 기능에 필수적인 여러 단백질과 당을 체외로 배출시켜 여러 질병을 일으키는 원인이 된다. 카드뭄 중독은 아주 쉽게 골절이 일어나는 이타이이타이병의 원인이며, 또한 설사, 복통, 심 한 구토를 수반하고, 생식 기능의 저해와 불임, 간장 및 신장 장애, 중추 신경계와 면역계의 손상, 정신 질환, 고혈 압, 암 발병 등을 초래할 수 있다. 미량으로도 장기간 섭취하 면 중독 증상이 나타날 수 있다. 니켈은 미국의 접촉성 피부 염 학회가 2008년에 ‘올해의 알레르기 유발물질'로 선정할 정도로 알레르기 피부 반응을 잘 일으킨다. 이 알레르기 반응은 한포증(pompholyx) 환자에게 특히 민감한 것으로 보이며, 니켈이 들어있는 귀걸이나 장신구를 착용하는 사 람들에게 자주 발생한다. 이에 따라 유럽 연합은 $0.05 \%$ 이상의 니켈이 들어 있는 귀걸이와 여러 니켈 도금 장신구 를 금지시켰다(2,7).

마지막으로, 알루미늄 화합물은 자연계에 널리 분포되어 있으나, 이들의 생물학적 역할은 아직 알려진 것이 없다. 알루미늄은 거의 독성이 없으며, 쥐를 이용한 동물 실험 결과 황산알루미늄의 치사량 $\left(\mathrm{LD}_{50}\right)$ 은 체중 $1 \mathrm{~kg}$ 당 약 6 $\mathrm{g}$ 인 것으로 밝혀졌다. 1980 년 대에 일부 과학자들이 알루미 늄이 치매와 관련될 수 있다고 제안하였으나, 아직 그 연관 성은 분명하지 않으며 계속 연구 중에 있다. 그러나 일부 연구에서는 섭취되는 알루미늄이 먹이 사슬에 의한 농축으
로 건강에 위해한 것으로 간주되고, 중추신경, 골격계, 조혈 계에서 독성을 일으키고, 알츠하이머와 같은 신경변성 질 병을 유발하는 것으로 보고되고 있다(2-4). 조리 기구에 의 한 알루미늄의 용출에 대해서는 2006년 Gramiccioni 등(5) 이 토마토 주스를 알루미늄 조리 기구에서 조리하였을 때 알루미늄이 $3 \mathrm{mg} / \mathrm{kg}$ 에서 $5.5 \mathrm{mg} / \mathrm{kg}$ 로 증가하였다고 보고하 였다.

본 연구에서는 유통되고 있는 캠핑용 조리 기구가 식품 용 기구 및 용기·포장공전에서 제시되고 있는 재질별 기준 (금속제: 납, 비소, 카드뮴, 니켈, 불소수지: 납)에 적합한지 살펴보고, 국, 찌개, 전골 등을 즐기는 한국의 식생활에 맞추 어 사용 조건에 따른 납, 비소, 카드뮴, 니켈, 알루미늄 유해 금속 용출량의 변화를 비교하였다. 기준이 설정되어 있는 유해금속 뿐만 아니라 기준이 설정되어 있지 않은 유해금속 에 대하여도 다양한 용출 용액 사용과 용출 시간의 증가에 따른 변화 그리고 조리 기구 사용 중에 생길 수 있는 물리적 스크래치에 의한 유해 금속 용출량의 변화를 살펴봄으로써 캠핑용 조리 기구의 안전성 실태를 파악하고 올바른 사용법 을 제시하여, 향후 캠핑용 조리 기구에 대한 시민들의 안전 에 대한 인식 변화와 기준 설정의 기초 자료로 제공하고자 하였다.

\section{재료 및 방법}

\section{실험 재료}

실험 재료로 사용된 캠핑용품은 Table 1 과 같으며 대구 지역 대형 마트에서 유통되고 있는 스테인레스, 경질알루 미늄, 연질알루미늄 코펠 및 불소수지 코팅 불판 등 재질별 3 건씩 총 12 개 제품을 대상으로 용출 용액별, 가열 시간별로 108 회 실험하였다.

또한 물리적 스크래치를 가한 상태에서 용출 용액별로 36회 유해 금속 용출 실험을 실시하였다.

\section{시약 및 표준품}

Nitric acid(Junsei Chemical Co., Ltd., Tokyo, Japan)와 hydrochloric acid(Daejung chemicals \& Metals Co., Ltd.,

Table 1. Classification of the cooking utensil for camping used in this study

\begin{tabular}{cccccccccccc}
\hline & & \multicolumn{9}{c}{ No. of samples of solution } \\
\cline { 3 - 12 } Item & & \multicolumn{3}{c}{ Distilled water } & \multicolumn{2}{c}{ Citric acid solution $(0.5 \%)$} & \multicolumn{2}{c}{ NaCl solution $(1 \%)$} \\
\cline { 3 - 12 } & & $0.5 \mathrm{~h}$ & $2 \mathrm{~h}$ & $6 \mathrm{~h}$ & $0.5 \mathrm{~h}$ & $2 \mathrm{~h}$ & $6 \mathrm{~h}$ & $0.5 \mathrm{~h}$ & $2 \mathrm{~h}$ & $6 \mathrm{~h}$ \\
\hline Stainless steel & Pot & 3 & 3 & 3 & 3 & 3 & 3 & 3 & 3 & 3 \\
Hard aluminium & Pot & 3 & 3 & 3 & 3 & 3 & 3 & 3 & 3 & 3 \\
Soft aluminium & Pot & 3 & 3 & 3 & 3 & 3 & 3 & 3 & 3 & 3 \\
Fluorocarbon resin & Pan & 3 & 3 & 3 & 3 & 3 & 3 & 3 & 3 & 3 \\
\hline
\end{tabular}


Siheung, Korea)는 유해 중금속 분석용 등급을 사용하였으 며, 증류수는 Millipore사의 초 순수장치(Milli-Q Direct 16 system, Darmstadt, Germany)로 제조한 저항 값 $18.2 \mathrm{M} \Omega$ 이상인 정제수를 사용하였다. 분석을 위한 표준 용액은 Quality control standard 21(As, Be, Ca, Cd, Co, Cr, Cu, Fe, Li, Mg, Mn, Mo, Ni, Pb, Sb, Se, Sr, Ti, Tl, V, Zn 100 g/mL, Perkin Elmer, USA)과 $\mathrm{Al}(1,000 \mu \mathrm{g} / \mathrm{mL}$, Perkin Elmer)을 사 용하였으며 회수율 검증을 위해 ERA 표준인증물질(A Waters Company, P255-500)을 사용하였다.

\section{실험 용액 제조}

다양한 조건에서의 납, 비소, 카드뮴, 니켈 및 알루미늄의 용출을 살펴보기 위해 용출 용액을 증류수, $0.5 \%$ citric acid 용액 및 $1 \% \mathrm{NaCl}$ 용액으로 준비하여 식품용 기구 및 용기 - 포장 공전에 따라 $100^{\circ} \mathrm{C}$ 로 유지하면서 30 분, 2 시간, 6 시간 용출 시간을 달리하면서 실험용액을 제조하였다. 또한 캠 핑용품의 사용 빈도에 따른 용출 정도를 알아보기 위해 각 재질별 시료에 Glass plate cutter(Diamond Tipped With Turet Head, Newfield, NY, USA)를 사용하여 $5 \mathrm{~cm}$ 의 스크래 치 5 개를 인위적으로 각 용기 바닥에 내고 위와 동일한 방법으로 $100^{\circ} \mathrm{C}$ 로 유지하면서 30 분의 용출 시간을 주어 실험용액을 제조하였다.

\section{기기 조건 및 분석 방법}

납, 비소, 카드뮴, 니켈 및 알루미늄의 유해 금속 분석은 유도결합플라즈마 발광광도측정기(ICP-OES, Optima 8300 $\mathrm{DV}$, Perkin Elmer, USA)를 사용하였으며 분석 조건은 Table 2 와 같다.

Table 2. Operating conditions and data acquisition parameters for ICP-OES spectrometer

\begin{tabular}{cccc}
\hline Parameter & Wavelength & Parameter & Operating conditions \\
\hline $\mathrm{Pb}$ & 220.353 & RF power & 1,300 watts \\
$\mathrm{As}$ & 193.696 & Nebulizer flow & $0.65 \mathrm{~L} / \mathrm{min}$ \\
$\mathrm{Cd}$ & 228.802 & Auxiliary flow & $0.2 \mathrm{~L} / \mathrm{min}$ \\
$\mathrm{Ni}$ & 231.604 & Plasma flow & $12.0 \mathrm{~L} / \mathrm{min}$ \\
$\mathrm{Al}$ & 396.153 & Sample flow & $1.5 \mathrm{~L} / \mathrm{min}$ \\
\hline
\end{tabular}

검량선 작성 및 검출 한계, 정량 한계

검출 한계, 정량 한계 및 회수율 실험을 위하여 유리 용기 를 공실험용으로 사용하였다. 검량선 작성은 납, 비소, 카드 뮴, 니켈 및 알루미늄 표준 용액을 증류수, $0.5 \%$ citric acid 용액 및 $1 \% \mathrm{NaCl}$ 용액으로 희석하여 $0.01,0.2,1,2 \mu \mathrm{g} / \mathrm{mL}$ 의 농도에서 검량선을 작성하였으며, linearity $\left(R^{2}\right)=0.9998$ 이 상으로 양호한 직선성을 보여 주었다(Table 3).

검출 한계와 정량 한계는 공실험용 유리 용기에 증류수, $0.5 \%$ citric acid 용액 및 $1 \% \mathrm{NaCl}$ 용액으로 납, 비소, 카드뮴,
니켈 및 알루미늄 표준 용액을 희석한 후(납, 비소, 카드뮴, 니켈 및 알루미늄 $0.05 \mu \mathrm{g} / \mathrm{mL}) 100^{\circ} \mathrm{C}$ 로 유지하면서 30 분간 용출시킨 각 7 개의 시료를 측정하여 검출 한계, 정량 한계 값을 계산하였다(Table 4)(8,9).

Table 3. Linearity of the hazardous metals according to different migrant solution

\begin{tabular}{cccc}
\hline Parameter & Distilled water & $\begin{array}{c}\text { Citric acid solution } \\
(0.5 \%)\end{array}$ & $\mathrm{NaCl}$ solution (1\%) \\
\hline $\mathrm{Pb}$ & $>0.9999$ & $>0.9999$ & $>0.9999$ \\
$\mathrm{As}$ & $>0.9999$ & $>0.9999$ & $>0.9999$ \\
$\mathrm{Cd}$ & $>0.9999$ & $>0.9999$ & $>0.9999$ \\
$\mathrm{Ni}$ & $>0.9999$ & $>0.9999$ & $>0.9999$ \\
$\mathrm{Al}$ & $>0.9998$ & $>0.9998$ & $>0.9999$ \\
\hline
\end{tabular}

Table 4. LOD and LOQ of the hazardous metals according to different migrant solution at $100^{\circ} \mathrm{C}$ for $30 \mathrm{~min}$

$(\mu \mathrm{g} / \mathrm{kg})$

\begin{tabular}{|c|c|c|c|c|c|c|}
\hline \multirow{2}{*}{ Parameter } & \multicolumn{2}{|c|}{ Distilled water } & \multicolumn{2}{|c|}{$\begin{array}{l}\text { Citric acid solution } \\
\quad(0.5 \%)\end{array}$} & \multicolumn{2}{|c|}{$\mathrm{NaCl}$ solution $(1 \%)$} \\
\hline & $\mathrm{LOD}^{1)}$ & $\mathrm{LOQ}^{2)}$ & LOD & LOQ & LOD & LOQ \\
\hline $\mathrm{Pb}$ & 2.48 & 8.81 & 1.02 & 3.36 & 2.84 & 9.37 \\
\hline As & 2.00 & 6.59 & 1.66 & 5.47 & 2.46 & 8.11 \\
\hline $\mathrm{Cd}$ & 0.45 & 1.48 & 0.47 & 1.56 & 0.53 & 1.75 \\
\hline $\mathrm{Ni}$ & 0.57 & 1.89 & 0.28 & 0.91 & 1.42 & 4.68 \\
\hline $\mathrm{Al}$ & 3.95 & 13.02 & 1.60 & 5.30 & 1.80 & 5.95 \\
\hline
\end{tabular}

${ }^{1)}$ Limit of detection $=3 \times \sigma / \mathrm{m}$

$(\sigma$, standard deviation of area; $\mathrm{m}$, slope of calibration curve).

${ }^{2)}$ Limit of quantification=3.3 $\times$ LOD.

회수율 실험은 공실험용 유리 용기에 용출 용액을 증류 수, $0.5 \%$ citric acid 용액 및 $1 \% \mathrm{NaCl}$ 용액으로 납, 비소, 카드뮴, 니켈 및 알루미늄 표준 용액을 희석한 후(납, 비소, 카드뮴, 니켈, 알루미늄 $0.5(\mathrm{\mu g} / \mathrm{kg}) / \mathrm{mL}) 100^{\circ} \mathrm{C}$ 로 유지하면서 30 분간 용출시킨 각 3 개의 시료를 측정하여 회수율 값을 계산하였다(Table 5).

표준물질의 회수율 실험은 회수율 검증 및 분해 효율과 측정 감도를 비교하기 위하여 일정 농도의 금속을 함유하고 있는 ERA 표준인증물질을 이용하여 용출 용액을 증류수, $0.5 \%$ citric acid 용액 및 $1 \% \mathrm{NaCl}$ 용액으로 희석한 후 식품 용 기구 및 용기· 포장 공전에 따라 $100^{\circ} \mathrm{C}$ 로 유지하면서 30 분간 용출시킨 각 3 개의 시료를 측정하여 회수율 값을 계산하였다(Table 6).

통계 처리

모든 실험은 3 회 반복을 실시하여 평균치와 표준편차로 나타내었고, IBM SPSS Statics 23을 이용하여 일원분산분 석과 사후검정으로 ANOVA(Analysis of variance)를 사용하 
Table 5. Recovery rates of the hazardous metals according to different migrant solution at $100^{\circ} \mathrm{C}$ for $30 \mathrm{~min}$

\begin{tabular}{ccccccc}
\hline \multirow{2}{*}{ Parameter } & \multicolumn{2}{c}{ Distilled water } & \multicolumn{2}{c}{ Citric acid solution $(0.5 \%)$} & \multicolumn{2}{c}{ NaCl solution $(1 \%)$} \\
\cline { 2 - 7 } & Recovery $(\%)^{1)}$ & RSD $(\%)^{2)}$ & Recovery $(\%)$ & RSD $(\%)$ & Recovery $(\%)$ & RSD $(\%)$ \\
\hline $\mathrm{Pb}$ & 100.5 & 1.22 & 101.3 & 0.82 & 99.8 & 1.26 \\
$\mathrm{As}$ & 99.8 & 1.51 & 101.2 & 0.53 & 103.9 & 0.91 \\
$\mathrm{Cd}$ & 101.1 & 0.94 & 101.6 & 1.10 & 100.6 & 1.94 \\
$\mathrm{Ni}$ & 103.3 & 0.68 & 105.1 & 0.44 & 104.5 & 2.64 \\
$\mathrm{Al}$ & 100.4 & 0.87 & 101.5 & 2.07 & 99.4 & 2.42 \\
\hline
\end{tabular}

${ }^{11}$ Average values obtained from three measurements.

${ }^{2)}$ Standard deviation/Average value $\times 100$.

Table 6. Measurement of certified reference material (CRM) according to different migrant solution at $100^{\circ} \mathrm{C}$ for $30 \mathrm{~min}$

\begin{tabular}{|c|c|c|c|c|c|c|c|}
\hline \multirow[b]{2}{*}{ Element } & \multirow[b]{2}{*}{ Migrant solution } & \multicolumn{2}{|c|}{ Certified } & \multicolumn{2}{|c|}{ Measured } & \multirow{2}{*}{$\begin{array}{c}\text { Recovery } \\
(\%)\end{array}$} & \multirow{2}{*}{$\begin{array}{l}\text { RSD } \\
(\%)^{3)}\end{array}$} \\
\hline & & $\begin{array}{c}\text { Average } \\
(\mu \mathrm{g} / \mathrm{mL})^{1)}\end{array}$ & $\begin{array}{c}\text { Uncertainty } \\
(\%)\end{array}$ & $\begin{array}{l}\text { Average } \\
(\mu \mathrm{g} / \mathrm{mL})\end{array}$ & $\mathrm{SD}^{2)}$ & & \\
\hline \multirow{3}{*}{$\mathrm{Pb}$} & Distilled water & & & 0.302 & 0.004 & 100.1 & 1.38 \\
\hline & Citric acid solution $(0.5 \%)$ & 0.302 & 0.466 & 0.306 & 0.003 & 101.2 & 1.05 \\
\hline & $\mathrm{NaCl}$ solution $(1 \%)$ & & & 0.303 & 0.005 & 100.3 & 1.75 \\
\hline \multirow{3}{*}{ As } & Distilled water & & & 0.393 & 0.008 & 101.0 & 2.08 \\
\hline & Citric acid solution $(0.5 \%)$ & 0.389 & 0.574 & 0.393 & 0.002 & 101.1 & 0.39 \\
\hline & $\mathrm{NaCl}$ solution $(1 \%)$ & & & 0.402 & 0.004 & 103.3 & 1.12 \\
\hline \multirow{3}{*}{$\mathrm{Cd}$} & Distilled water & & & 0.751 & 0.004 & 101.0 & 0.50 \\
\hline & Citric acid solution $(0.5 \%)$ & 0.743 & 0.460 & 0.755 & 0.006 & 101.7 & 0.73 \\
\hline & $\mathrm{NaCl}$ solution $(1 \%)$ & & & 0.756 & 0.010 & 101.7 & 1.33 \\
\hline \multirow{3}{*}{$\mathrm{Ni}$} & Distilled water & & & 1.198 & 0.003 & 104.1 & 0.26 \\
\hline & Citric acid solution $(0.5 \%)$ & 1.150 & 0.458 & 1.213 & 0.002 & 105.4 & 0.17 \\
\hline & $\mathrm{NaCl}$ solution $(1 \%)$ & & & 1.207 & 0.012 & 105.0 & 0.99 \\
\hline \multirow{3}{*}{$\mathrm{Al}$} & Distilled water & & & 1.833 & 0.020 & 93.5 & 1.10 \\
\hline & Citric acid solution $(0.5 \%)$ & 1.960 & 4.980 & 1.847 & 0.013 & 94.2 & 0.72 \\
\hline & $\mathrm{NaCl}$ solution $(1 \%)$ & & & 1.865 & 0.011 & 95.1 & 0.59 \\
\hline
\end{tabular}

${ }^{1)}$ Average values obtained from three measurement.

${ }^{2)}$ Standard deviation.

${ }^{3}$ Standard deviation/Average value $\times 100$.

여 평균값들 간의 유의성을 검정하였다 $(\mathrm{p}<0.05)$.

\section{결과 및 고찰}

\section{용출 용액에 따른 재질별 유해 금속 용출량}

$100^{\circ} \mathrm{C}$ 에서 30 분간 가열한, 용출 용액에 따른 재질별 납, 비소, 카드뮴, 니켈 및 알루미늄 평균 용출량은 Table 7과 같다. 스테인레스 재질 코펠은 $0.5 \%$ citric acid 용액에서 니켈 $0.007 \mathrm{mg} / \mathrm{L}$ 와 알루미늄 $0.021 \mathrm{mg} / \mathrm{L}, 1 \% \mathrm{NaCl}$ 용액에 서 비소 $0.006 \mathrm{mg} / \mathrm{L}$ 가 검출되었으며, 다른 조건에서는 불검 출 또는 $0.001 \mathrm{mg} / \mathrm{L}$ 이하였다. 경질알루미늄 재질 코펠은
증류수에서 알루미늄 $0.007 \mathrm{mg} / \mathrm{L}, 0.5 \%$ citric acid 용액에서 니켈 $0.005 \mathrm{mg} / \mathrm{L}$ 와 알루미늄 $51.97 \mathrm{mg} / \mathrm{L}, 1 \% \mathrm{NaCl}$ 용액에 서 비소 $0.008 \mathrm{mg} / \mathrm{L}$ 가 검출되었으며, 다른 조건에서는 불검 출 또는 $0.002 \mathrm{mg} / \mathrm{L}$ 이하였다. 연질알루미늄 재질 코펠은 $0.5 \%$ citric acid 용액에서 알루미늄 $24.89 \mathrm{mg} / \mathrm{L}, 1 \% \mathrm{NaCl}$ 용액에서 비소 $0.006 \mathrm{mg} / \mathrm{L}$ 가 검출되었으며, 다른 조건에서 는 불검출 또는 $0.002 \mathrm{mg} / \mathrm{L}$ 이하였다. 마지막으로, 불소수지 코팅 불판은 $0.5 \%$ citric acid 용액에서 알루미늄 $0.040 \mathrm{mg} / \mathrm{L}$ 가 검출되었으며, 다른 조건에서는 불검출 또는 $0.001 \mathrm{mg} / \mathrm{L}$ 이하였다.

식품용 기구 및 용기·포장 공전에 따른 금속제의 중금속 용출량의 규격 기준은 납 $0.4 \mathrm{mg} / \mathrm{L}$ 이하, 비소 $0.2 \mathrm{mg} / \mathrm{L}$ 
Table 7. Average concentration of the migrated hazardous metals according to different migrant solutions at $100^{\circ} \mathrm{C}$ for $30 \mathrm{~min}$

\begin{tabular}{|c|c|c|c|c|c|c|}
\hline Materials & solution & $\mathrm{Pb}$ & As & $\mathrm{Cd}$ & $\mathrm{Ni}$ & $\mathrm{Al}$ \\
\hline \multirow{3}{*}{ Stainless steel } & Distilled water & $\mathrm{ND}^{1)}$ & $\begin{array}{l}0.001\left(0.0011^{2)}\right. \\
\text { ND-0.002) }\end{array}$ & ND & $\begin{array}{l}0.000(0.001) \\
\text { ND-0.001 }\end{array}$ & ND \\
\hline & $\begin{array}{c}\text { Citric acid } \\
\text { solution }(0.5 \%)\end{array}$ & $\begin{array}{c}0.001(0.001) \\
\text { ND-0.002 }\end{array}$ & $\begin{array}{l}0.001(0.002) \\
\text { ND-0.003 }\end{array}$ & ND & $\begin{array}{c}0.007(0.003) \\
0.005-0.010\end{array}$ & $\begin{array}{c}0.021(0.009) \\
0.012-0.029\end{array}$ \\
\hline & $\mathrm{NaCl}$ solution $(1 \%)$ & ND & $\begin{array}{c}0.006(0.001) \\
0.005-0.007\end{array}$ & ND & ND & $\begin{array}{l}0.001(0.002) \\
\text { ND-0.003 }\end{array}$ \\
\hline \multirow{3}{*}{$\begin{array}{c}\text { Hard } \\
\text { aluminium }\end{array}$} & Distilled water & ND & $\begin{array}{l}0.001(0.002) \\
\text { ND-0.003 }\end{array}$ & ND & $\begin{array}{c}0.001(0.001) \\
\text { ND-0.001 }\end{array}$ & $\begin{array}{c}0.007(0.001)^{* 4)} \\
0.006-0.008\end{array}$ \\
\hline & $\begin{array}{c}\text { Citric acid } \\
\text { solution }(0.5 \%)\end{array}$ & $\begin{array}{c}0.000(0.001) \\
\text { ND-0.001 }\end{array}$ & $\mathrm{ND}$ & ND & $\begin{array}{c}0.005(0.002)^{* *} \\
0.003-0.006\end{array}$ & $\begin{array}{c}51.97(4.402) \\
47.50-56.30\end{array}$ \\
\hline & $\mathrm{NaCl}$ solution $(1 \%)$ & ND & $\begin{array}{c}0.008(0.002) \\
0.007-0.010\end{array}$ & ND & ND & $\begin{array}{l}0.002(0.002) \\
\text { ND-0.003 }\end{array}$ \\
\hline \multirow{3}{*}{$\begin{array}{c}\text { Soft } \\
\text { aluminium }\end{array}$} & Distilled water & ND & $\mathrm{ND}$ & ND & $\begin{array}{c}0.001(0.000) \\
0.001\end{array}$ & $\begin{array}{l}0.001(0.002) \\
\text { ND-0.004 }\end{array}$ \\
\hline & $\begin{array}{c}\text { Citric acid } \\
\text { solution }(0.5 \%)\end{array}$ & ND & $\mathrm{ND}$ & ND & $\begin{array}{c}0.002(0.000)^{* * *} \\
0.002\end{array}$ & $\begin{array}{c}24.89(3.130)^{* * * *} \\
21.45-27.57\end{array}$ \\
\hline & $\mathrm{NaCl}$ solution $(1 \%)$ & ND & $\begin{array}{c}0.006(0.002) \\
0.004-0.008\end{array}$ & ND & $\begin{array}{c}0.000(0.001) \\
\text { ND-0.001 }\end{array}$ & $\begin{array}{l}0.002(0.002) \\
\text { ND-0.003 }\end{array}$ \\
\hline \multirow{3}{*}{$\begin{array}{l}\text { Fluoro- } \\
\text { carbon resin }\end{array}$} & Distilled water & $\mathrm{ND}$ & $\begin{array}{c}0.001(0.002) \\
\text { ND-0.003 }\end{array}$ & $\mathrm{ND}$ & $\begin{array}{l}0.001(0.001) \\
\text { ND-0.001 }\end{array}$ & ND \\
\hline & $\begin{array}{c}\text { Citric acid } \\
\text { solution }(0.5 \%)\end{array}$ & $\begin{array}{l}0.001(0.001) \\
\text { ND-0.002 }\end{array}$ & $\begin{array}{c}0.001(0.001) \\
\text { ND-0.002 }\end{array}$ & ND & ND & $\begin{array}{c}0.040(0.003)^{* * * * *} \\
0.037-0.043\end{array}$ \\
\hline & $\mathrm{NaCl}$ solution $(1 \%)$ & ND & $\begin{array}{l}0.001(0.002) \\
\text { ND-0.004 }\end{array}$ & ND & $\begin{array}{l}0.000(0.001) \\
\text { ND-0.001 }\end{array}$ & $\begin{array}{l}0.001(0.001) \\
\text { ND-0.002 }\end{array}$ \\
\hline
\end{tabular}

\footnotetext{
${ }^{1)}$ Not detected.

${ }^{2)}$ Average (Standard Deviation)

${ }^{3)}$ Minimum concentration-Maximum concentration.

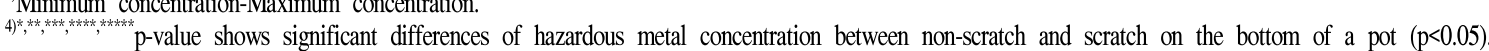

이하, 카드뮴 $0.1 \mathrm{mg} / \mathrm{L}$ 이하, 니켈 $0.1 \mathrm{mg} / \mathrm{L}$ 이하로 본 연구 결과에서는 모두 기준에 적합한 것으로 나타났다. Choi 등 (10)과 Lee 등(11)의 조사에서도 기준을 초과한 경우는 없었 다. 규격 기준이 없는 알루미늄의 경우는 $0.5 \%$ citric acid 용액에서 스테인레스 재질 코펠 $0.021 \mathrm{mg} / \mathrm{L}$, 경질알루미늄 재질 코펠 $51.97 \mathrm{mg} / \mathrm{L}$, 연질알루미늄 재질 코펠 $24.89 \mathrm{mg} / \mathrm{L}$ 로 높게 용출되었다. 최고 $236.93 \mathrm{mg} / \mathrm{L}$ 까지 용출되었다는 식품의약품안전처의 2005년 조사결과(12)보다는 낮은 수 준이며 제품 종류에 따라 용출량에 차이가 있는 것으로 보인다.

비소는 $1 \% \mathrm{NaCl}$ 용액에서 스테인레스와 연질알루미늄 재질 코펠 $0.006 \mathrm{mg} / \mathrm{L}$, 경질알루미늄 재질 코펠 $0.008 \mathrm{mg} / \mathrm{L}$ 로 증류수와 $0.5 \%$ citric acid 용액에서 보다 다소 높게 용출 되었다. 니켈은 $0.5 \%$ citric acid 용액에서 스테인레스 재질 코펠이 $0.007 \mathrm{mg} / \mathrm{L}$ 로 증류수와 $1 \% \mathrm{NaCl}$ 용액에서 보다 다소 높게 용출되었는데, 이는 스테인레스 304 코펠의 8.0-10.5\% 니켈 조성 특성 때문으로 사료된다.

용출 용액에 따른 재질별 유해 금속 용출량 분석 결과, 산성 조건에서는 알루미늄 용출량이 증가하고, 염기성 조
건에서는 비소 용출량이 증가하는 것으로 나타나 $\mathrm{Kim}$ 등 (13), Lee 등(14)의 연구 결과와 유사한 결과를 얻었다. 따라 서 알루미늄 재질 코펠의 경우, $\mathrm{pH}$ 가 낮은 음식인 김치, 과일주스, 소스류 등을 담아두거나 산을 첨가하는 조리법 을 피하는 것이 의도하지 않는 알루미늄의 섭취를 줄일 수 있는 안전한 방법으로 생각된다. 다른 용출 용액에 비해 $1 \% \mathrm{NaCl}$ 용액에서 비소가 비교적 높게 검출되었는데 이는 소금물과 비소 용출에 관하여 그 상관관계에 대한 보충 연구가 더 필요할 것으로 사료된다.

물리적 스크래치를 가한 후 용출 용액에 따른 재질별 유 해 금속 용출량

물리적 스크래치를 가한 후 $100^{\circ} \mathrm{C}$ 에서 30 분간 가열한 용출 용액에 따른 재질별 유해 금속 평균 용출량은 Table 8 과 같다. 스테인레스 재질 코펠은 $0.5 \%$ citric acid 용액에서 니켈 $0.009 \mathrm{mg} / \mathrm{L}$ 와 알루미늄 $0.021 \mathrm{mg} / \mathrm{L}, 1 \% \mathrm{NaCl}$ 용액에 서 비소 $0.009 \mathrm{mg} / \mathrm{L}$ 가 검출되었으며, 다른 조건에서는 불검 출 또는 $0.001 \mathrm{mg} / \mathrm{L}$ 이하였다. 경질알루미늄 재질 코펠은 증류수에서 알루미늄 $0.025 \mathrm{mg} / \mathrm{L}, 0.5 \%$ citric acid 용액에서 
Table 8. Average concentration of the migrated hazardous metals according to different migrant solutions and scratch on the bottom of a pot at $100^{\circ} \mathrm{C}$ for $30 \mathrm{~min}$

\begin{tabular}{|c|c|c|c|c|c|c|}
\hline Materials & Solution & $\mathrm{Pb}$ & As & $\mathrm{Cd}$ & $\mathrm{Ni}$ & $\mathrm{Al}$ \\
\hline \multirow{3}{*}{ Stainless steel } & Distilled water & $\mathrm{ND}^{1)}$ & ND & $\mathrm{ND}$ & $\begin{array}{c}0.000(0.001)^{2)} \\
\text { ND-0.001 }\end{array}$ & ND \\
\hline & $\begin{array}{c}\text { Citric acid } \\
\text { solution }(0.5 \%)\end{array}$ & $\begin{array}{c}0.000(0.001) \\
\text { ND-0.001 }\end{array}$ & $\mathrm{ND}$ & $\begin{array}{c}0.000(0.001) \\
\text { ND- } 0.001\end{array}$ & $\begin{array}{c}0.009(0.001) \\
0.009-0.010\end{array}$ & $\begin{array}{c}0.021(0.008) \\
0.013-0.028\end{array}$ \\
\hline & $\begin{array}{l}\mathrm{NaCl} \text { solution } \\
(1 \%)\end{array}$ & $\mathrm{ND}$ & $\begin{array}{c}0.009(0.004) \\
0.004-0.012\end{array}$ & $\mathrm{ND}$ & $\mathrm{ND}$ & $\begin{array}{l}0.001(0.001) \\
\text { ND-0.002 }\end{array}$ \\
\hline \multirow{3}{*}{$\begin{array}{c}\text { Hard } \\
\text { aluminium }\end{array}$} & Distilled water & ND & $\mathrm{ND}$ & $\mathrm{ND}$ & $\begin{array}{c}0.000(0.001) \\
\text { ND-0.001 }\end{array}$ & $\begin{array}{c}0.025(0.004)^{* 4)} \\
0.022-0.030\end{array}$ \\
\hline & $\begin{array}{c}\text { Citric acid } \\
\text { solution }(0.5 \%)\end{array}$ & ND & $\mathrm{ND}$ & $\begin{array}{c}0.001(0.001) \\
\text { ND-0.002 }\end{array}$ & $\begin{array}{c}0.014(0.002)^{* *} \\
0.013-0.017\end{array}$ & $\begin{array}{c}53.86(3.411) \\
50.30-57.10\end{array}$ \\
\hline & $\begin{array}{l}\mathrm{NaCl} \text { solution } \\
(1 \%)\end{array}$ & ND & $\begin{array}{c}0.010(0.006) \\
0.004-0.015\end{array}$ & ND & $\mathrm{ND}$ & $\begin{array}{c}0.005(0.002) \\
0.004-0.007\end{array}$ \\
\hline \multirow{3}{*}{$\begin{array}{c}\text { Soft } \\
\text { aluminium }\end{array}$} & Distilled water & $\begin{array}{c}0.001(0.002) \\
\text { ND-0.003 }\end{array}$ & $\begin{array}{c}0.001(0.002) \\
\text { ND-0.003 }\end{array}$ & $\mathrm{ND}$ & $\begin{array}{c}0.001(0.002) \\
\text { ND-0.003 }\end{array}$ & ND \\
\hline & $\begin{array}{c}\text { Citric acid } \\
\text { solution }(0.5 \%)\end{array}$ & $\begin{array}{c}0.003(0.003) \\
\text { ND-0.006 }\end{array}$ & $\mathrm{ND}$ & ND & $\begin{array}{c}0.011(0.001)^{* \star *} \\
0.010-0.012\end{array}$ & $\begin{array}{c}31.78(1.662)^{* * * *} \\
30.25-33.55\end{array}$ \\
\hline & $\begin{array}{l}\mathrm{NaCl} \text { solution } \\
(1 \%)\end{array}$ & ND & $\begin{array}{c}0.006(0.003) \\
0.003-0.009\end{array}$ & $\mathrm{ND}$ & $\mathrm{ND}$ & $\begin{array}{c}0.007(0.005) \\
0.003-0.012\end{array}$ \\
\hline \multirow{3}{*}{$\begin{array}{l}\text { Fluoro- } \\
\text { carbon resin }\end{array}$} & Distilled water & ND & $\begin{array}{l}0.001(0.001) \\
\text { ND-0.002 }\end{array}$ & $\mathrm{ND}$ & $\mathrm{ND}$ & $\begin{array}{l}0.001(0.002) \\
\text { ND-0.004 }\end{array}$ \\
\hline & $\begin{array}{c}\text { Citric acid } \\
\text { solution }(0.5 \%)\end{array}$ & $\begin{array}{c}0.003(0.001) \\
0.002-0.004\end{array}$ & $\begin{array}{l}0.002(0.003) \\
\text { ND-0.005 }\end{array}$ & $\mathrm{ND}$ & $\begin{array}{l}0.000(0.001) \\
\text { ND-0.001 }\end{array}$ & $\begin{array}{c}0.055(0.008)^{* * * * *} \\
0.048-0.064\end{array}$ \\
\hline & $\begin{array}{l}\mathrm{NaCl} \text { solution } \\
(1 \%)\end{array}$ & ND & $\begin{array}{c}0.003(0.003) \\
\text { ND-0.006 }\end{array}$ & ND & $\begin{array}{c}0.001(0.001) \\
\text { ND-0.001 }\end{array}$ & $\begin{array}{c}0.003(0.002) \\
0.002-0.006\end{array}$ \\
\hline
\end{tabular}

\footnotetext{
${ }^{1)}$ Not detected.

${ }^{2)}$ Average (Standard Deviation).

${ }^{3}$ Minimum concentration-Maximum concentration.

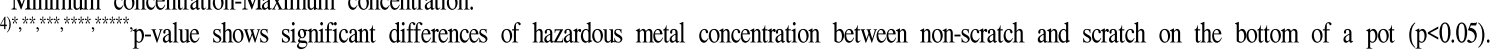

니켈 $0.014 \mathrm{mg} / \mathrm{L}$ 와 알루미늄 $53.86 \mathrm{mg} / \mathrm{L}, 1 \% \mathrm{NaCl}$ 용액에 서 비소 $0.010 \mathrm{mg} / \mathrm{L}$ 와 알루미늄 $0.005 \mathrm{mg} / \mathrm{L}$ 가 검출되었으 며, 다른 조건에서는 불검출 또는 $0.001 \mathrm{mg} / \mathrm{L}$ 이하였다. 연 질알루미늄 재질 코펠은 $0.5 \%$ citric acid 용액에서 니켈 $0.011 \mathrm{mg} / \mathrm{L}$ 와 알루미늄 $31.78 \mathrm{mg} / \mathrm{L}, 1 \% \mathrm{NaCl}$ 용액에서 비소 $0.006 \mathrm{mg} / \mathrm{L}$ 와 알루미늄 $0.007 \mathrm{mg} / \mathrm{L}$ 가 검출되었으며, 다른 조건에서는 불검출 또는 $0.003 \mathrm{mg} / \mathrm{L}$ 이하였다. 마지막 으로, 불소수지 코팅 불판은 $0.5 \%$ citric acid 용액에서 알루 미늄 $0.055 \mathrm{mg} / \mathrm{L}$ 로 검출되었으며, 다른 조건에서는 불검출 또는 $0.003 \mathrm{mg} / \mathrm{L}$ 이하였다.

스크래치를 가하기 전의 용출 용액에 따른 재질별 유해 금속 용출 결과(Table 7)와 물리적 스크래치를 가한 후의 용출 용액에 따른 재질별 유해 금속 용출 결과(Table 8)에 대하여 t-test를 실시한 결과, 경질알루미늄 재질 코펠은 증 류수에서 알루미늄, $0.5 \%$ citric acid 용액에서 니켈이 유의 하였으며, 연질알루미늄 재질 코펠은 $0.5 \%$ citric acid 용액 에서 니켈과 알루미늄이 유의하였고, 불소수지 코팅 불판 은 $0.5 \%$ citric acid 용액에서 알루미늄이 유의한 것으로 나타났다 $(\mathrm{p}<0.05)$.
물리적 스크래치를 가한 후 용출 용액에 따른 재질별 유해 금속 용출량은 스크래치가 없는 경우 보다 일부 조건 상에서 증가 되었다. 실제 더 많은 스크래치 상태에 있을 경우에는 유해 금속 용출량이 지속적으로 증가 될 것으로 사료된다.

용출 시간에 따른 재질별, 용출 용액별 유해 금속 용출량 의 변화

스테인레스, 경질알루미늄, 연질알루미늄 재질 코펠 및 불소수지 코팅 불판을 대상으로 용출 용액별로 가열 시간 $(0.5,2,6 \mathrm{~h})$ 을 늘여가며 조사한 결과는 Fig. 1-7과 같다. 가열 시간 증가에 따른 납의 평균 용출량은 $0.5 \%$ citric acid 용액에서 불소수지 코팅 불판이 $0.001 \mathrm{mg} / \mathrm{L}$ 에서 0.004 $\mathrm{mg} / \mathrm{L}$ 로 증가 되었다(Fig. 1). 스테인레스, 경질알루미늄, 연 질알루미늄 재질 코펠은 불검출 또는 $0.002 \mathrm{mg} / \mathrm{L}$ 이하로 용출 시간 증가에 따른 변화가 적게 나타났다.

가열 시간 증가에 따른 비소의 평균 용출량은 $0.5 \%$ citric acid용액에서 불소수지 코팅 불판이 $0.001 \mathrm{mg} / \mathrm{L}$ 에서 0.009 


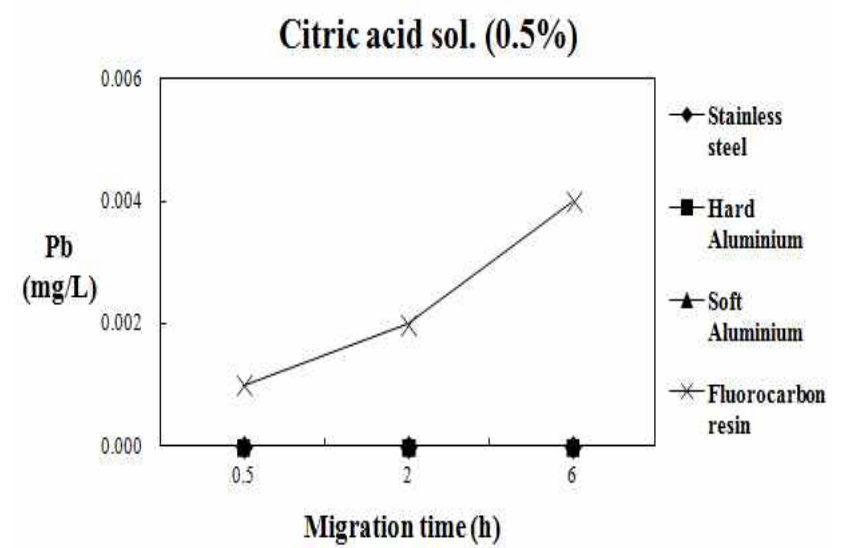

Fig. 1. Change of lead concentration as the increase of migrant time in $0.5 \%$ citric acid solution at stainless steel, hard aluminium, soft aluminium and fluorocarbon resin.

Results are shown as average bar (-) of three experiments in each samples $\boldsymbol{\Delta}, \times)$.

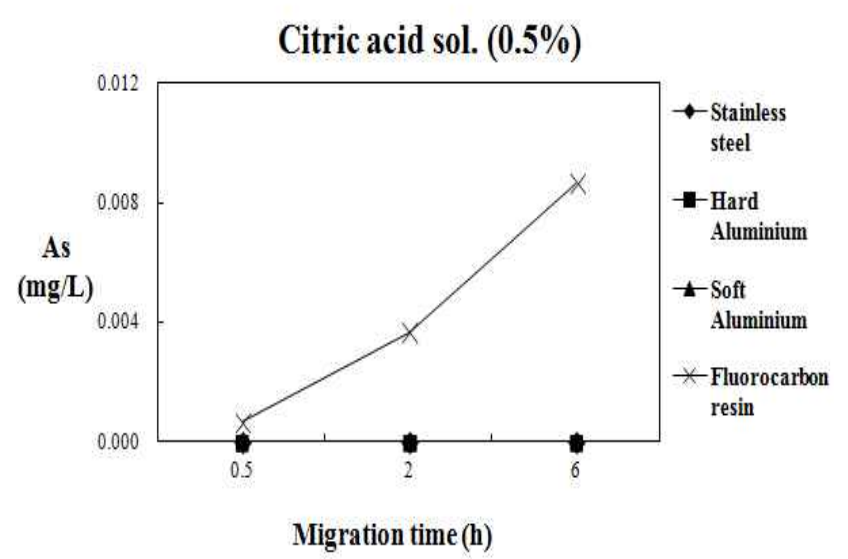

Fig. 2. Change of arsenic concentration as the increase of migrant time in $0.5 \%$ citric acid solution at stainless steel, hard aluminium, soft aluminium and fluorocarbon resin.

Results are shown as average bar $(-)$ of three experiments in each samples $\Delta, \times)$.

$\mathrm{mg} / \mathrm{L}$ 로 증가 되었고(Fig. 2), $1 \% \mathrm{NaCl}$ 용액에서는 스테인레 스 재질 코펠은 $0.006 \mathrm{mg} / \mathrm{L}$ 에서 $0.012 \mathrm{mg} / \mathrm{L}$ 로 경질알루미 늄 재질 코펠은 $0.008 \mathrm{mg} / \mathrm{L}$ 에서 $0.012 \mathrm{mg} / \mathrm{L}$, 연질알루미늄 재질 코펠은 $0.006 \mathrm{mg} / \mathrm{L}$ 에서 $0.011 \mathrm{mg} / \mathrm{L}$ 로 불소수지 코팅 불판은 $0.001 \mathrm{mg} / \mathrm{L}$ 에서 $0.007 \mathrm{mg} / \mathrm{L}$ 로 증가되었다(Fig. 3) 나머지 조건에서는 불검출 또는 $0.002 \mathrm{mg} / \mathrm{L}$ 이하로 용출 시간 증가에 따른 변화가 적게 나타났다.

카드뮴은 모든 재질 및 용출 용액 조건에서 불검출 또는 $0.002 \mathrm{mg} / \mathrm{L}$ 이하로 용출 시간 증가에 따른 변화가 적게 나타 났다.

가열 시간 증가에 따른 니켈의 평균 용출량은 $0.5 \%$ citric acid 용액에서 스테인레스 재질 코펠은 $0.007 \mathrm{mg} / \mathrm{L}$ 에서 $0.012 \mathrm{mg} / \mathrm{L}$ 로 경질알루미늄 재질 코펠은 $0.005 \mathrm{mg} / \mathrm{L}$ 에서 $0.014 \mathrm{mg} / \mathrm{L}$ 로 연질알루미늄 재질 코펠은 $0.002 \mathrm{mg} / \mathrm{L}$ 에서

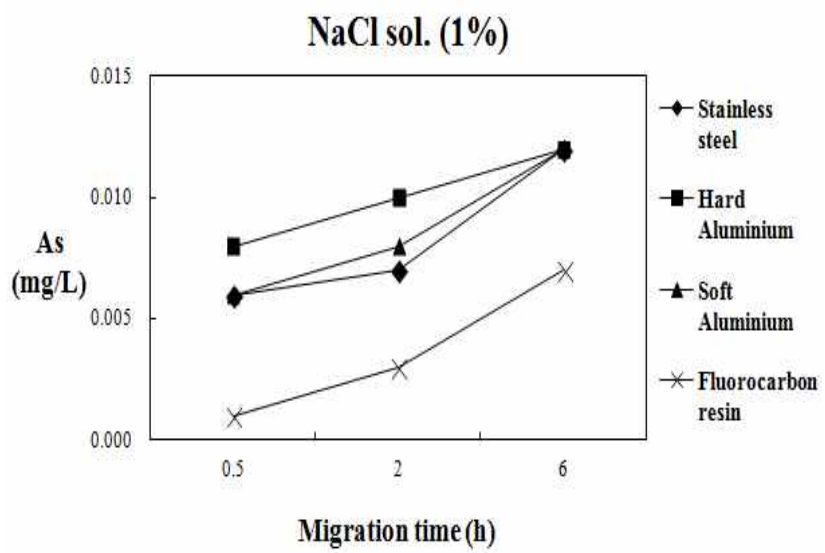

Fig. 3. Change of arsenic concentration as the increase of migrant time in $1 \% \mathrm{NaCl}$ solutoin at stainless steel, hard aluminium, soft aluminium and fluorocarbon resin.

Results are shown as average bar $(-)$ of three experiments in each samples ( $\boldsymbol{\Delta}, \times)$.

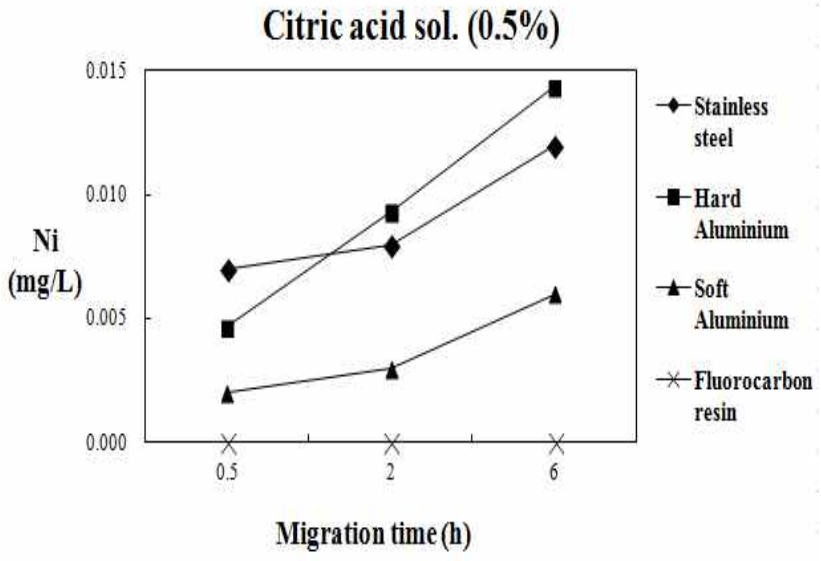

Fig. 4. Change of nickel concentration as the increase of migrant time in $0.5 \%$ citric acid solution at stainless steel, hard aluminium, soft aluminium and fluorocarbon resin.

Results are shown as average bar ( - ) of three experiments in each samples

$\boldsymbol{\Delta}, \mathrm{x}$.

$0.006 \mathrm{mg} / \mathrm{L}$ 로 증가되었다(Fig. 4). 나머지 조건에서는 불검 출 또는 $0.002 \mathrm{mg} / \mathrm{L}$ 이하로 용출 시간 증가에 따른 변화가 적게 나타났다.

가열 시간 증가에 따른 알루미늄의 평균 용출량은 증류 수에서 경질알루미늄 재질 코펠은 $0.007 \mathrm{mg} / \mathrm{L}$ 에서 0.019 $\mathrm{mg} / \mathrm{L}$ 로 연질알루미늄 재질 코펠은 $0.001 \mathrm{mg} / \mathrm{L}$ 에서 0.007 $\mathrm{mg} / \mathrm{L}$ 로 불소수지 코팅 불판은 불검출에서 $0.006 \mathrm{mg} / \mathrm{L}$ 로 증가 되었고(Fig. 5), $0.5 \%$ citric acid 용액에서 스테인레스 재질 코펠이 $0.021 \mathrm{mg} / \mathrm{L}$ 에서 $0.068 \mathrm{mg} / \mathrm{L}$ 로 경질알루미늄 재질 코펠은 $51.97 \mathrm{mg} / \mathrm{L}$ 에서 $96.47 \mathrm{mg} / \mathrm{L}$ 로 연질알루미늄 재질 코펠은 $24.89 \mathrm{mg} / \mathrm{L}$ 에서 $72.71 \mathrm{mg} / \mathrm{L}$ 로 불소수지 코팅 불판은 $0.040 \mathrm{mg} / \mathrm{L}$ 에서 $0.190 \mathrm{mg} / \mathrm{L}$ 로 증가되었다(Fig. 6). $1 \% \mathrm{NaCl}$ 용액에서 가열 시간 증가에 따른 알루미늄의 평균 용출량은 연질알루미늄 재질 코펠이 $0.002 \mathrm{mg} / \mathrm{L}$ 에서 0.008 


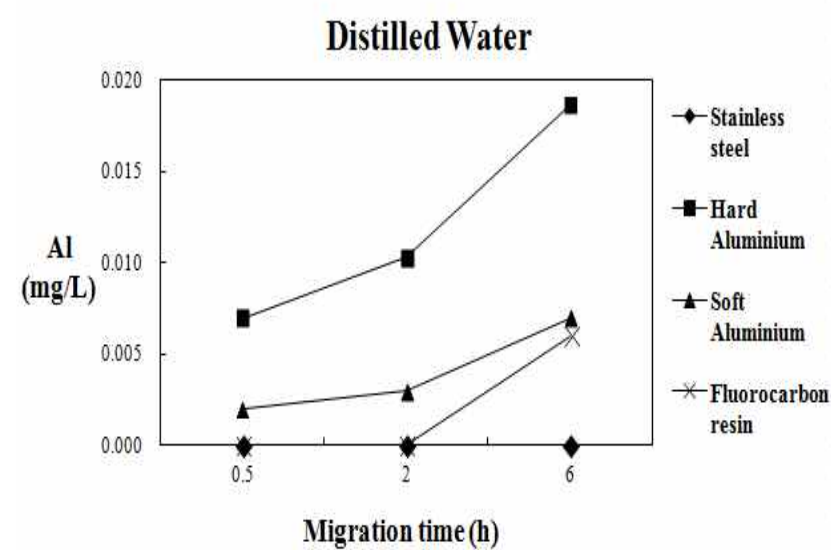

Fig. 5. Change of aluminium concentration as the increase of migrant time in distilled water at stainless steel, hard aluminium, soft aluminium and fluorocarbon resin.

Results are shown as average bar (-) of three experiments in each samples $\boldsymbol{\Delta}, \mathrm{x}$.

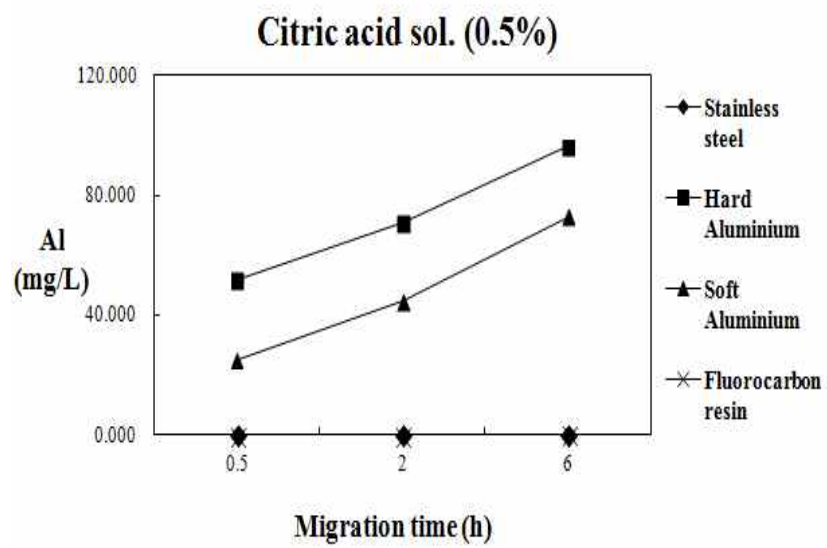

Fig. 6. Change of aluminium concentration as the increase of migrant time in $0.5 \%$ citric acid solution at stainless steel, hard aluminium, soft aluminium and fluorocarbon resin.

Results are shown as average bar ( $(-)$ of three experiments in each samples $\boldsymbol{\Delta}, \times)$.

$\mathrm{mg} / \mathrm{L}$ 로 증가되었다(Fig. 7). 나머지 조건에서는 불검출 또 는 $0.002 \mathrm{mg} / \mathrm{L}$ 이하로 용출 시간 증가에 따른 변화가 적게 나타났다.

스테인레스 재질 코펠은 가열 시간이 증가할수록 $0.5 \%$ citric acid 용액에서 니켈과 알루미늄 용출량이 2-3배 증가 하였고, $1 \% \mathrm{NaCl}$ 용액에서는 비소 용출량이 2배 증가하였 다. 경질알루미늄과 연질알루미늄 재질 코펠의 경우, $0.5 \%$ citric acid 용액에서 니켈과 알루미늄 용출량은 2-3배 증가 하였고, $1 \% \mathrm{NaCl}$ 용액에서 비소는 1.5 배 정도 증가하였다. 스테인레스와 알루미늄 재질 코펠은 산성과 염기성 조건에 서 장시간 조리하지 않는 것이 바람직하며 식품으로의 중금 속 이행을 줄일 수 있을 것으로 사료된다.

불소수지 코팅 불판은 가열 시간이 증가할수록 $0.5 \%$ citric acid 용액에서 납, 비소와 알루미늄 용출량이 4-5배 증가되는 것으로 나타났고, $1 \% \mathrm{NaCl}$ 용액에서 비소 용출량 이 3 배 정도 증가하였다. 불소수지 코팅 불판 역시 $\mathrm{pH}$ 가 낮은 음식을 장시간 조리하는 것은 바람직하지 않는 것으로 판단된다.

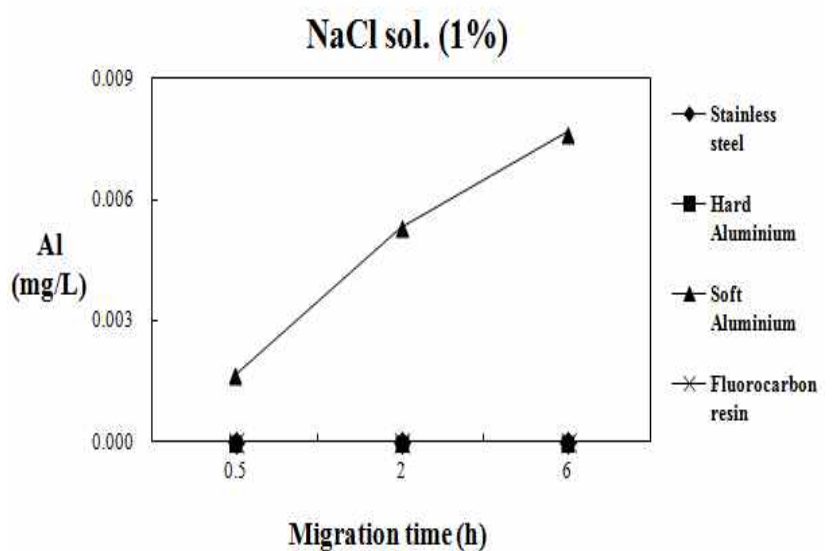

Fig. 7. Change of aluminium concentration as the increase of migrant time in $1 \% \mathrm{NaCl}$ solutoin at stainless steel, hard aluminium, soft aluminium and fluorocarbon resin.

Results are shown as average bar $(-)$ of three experiments in each samples ( $\boldsymbol{\Delta}, \mathrm{x}$.

\section{요 약}

대구시내 대형마트에서 유통되고 있는 스테인레스, 경질 알루미늄, 연질알루미늄 재질 코펠 및 불소수지 코팅 불판 에 대해 $0.5 \%$ citric acid 용액에서 용출되는 유해 금속을 유도결합플라즈마 발광광도측정기(ICP-OES)로 측정한 결 과, 식품용 기구 및 용기·포장 공전에 기준이 설정된 납, 카드뮴, 비소, 니켈의 경우는 모두 적합한 것으로 나타났다. 그러나 용출 용액과 사용 환경에 따라 그 용출 정도에 차이 가 있는 것으로 나타났다. 증류수, $0.5 \%$ citric acid 용액, $1 \% \mathrm{NaCl}$ 용액 등 용출 용액을 달리하여 30 분간 가열한 뒤 평균 용출량을 비교한 결과, 증류수에서 경질알루미늄 재질 코펠의 알루미늄 용출량이 $0.007 \mathrm{mg} / \mathrm{L}$ 수준이었으나, $0.5 \%$ citric acid 용액에서는 스테인레스 재질 코펠은 0.021 $\mathrm{mg} / \mathrm{L}$, 경질알루미늄 재질 코펠은 $51.97 \mathrm{mg} / \mathrm{L}$, 연질알루미 늄 재질 코펠은 $24.89 \mathrm{mg} / \mathrm{L}$, 불소수지 코팅 불판은 0.040 $\mathrm{mg} / \mathrm{L}$ 로 증류수와 $1 \% \mathrm{NaCl}$ 용액에서의 용출량보다 높았다. $1 \% \mathrm{NaCl}$ 용액에서 비소는 스테인레스와 연질알루미늄 재 질 코펠 $0.006 \mathrm{mg} / \mathrm{L}$, 경질알루미늄 재질 코펠 $0.008 \mathrm{mg} / \mathrm{L}$ 로 증류수와 $0.5 \%$ citric acid 용액에서의 용출량보다 다소 높게 용출되었다. $0.5 \%$ citric acid 용액에서 니켈이 스테인레스 재질 코펠이 $0.007 \mathrm{mg} / \mathrm{L}$ 로 증류수와 $1 \% \mathrm{NaCl}$ 용액에서의 용출량보다 다소 높게 용출되었는데, 이는 스테인레스 코 펠의 니켈 조성 특성 때문으로 사료된다. 카드뮴은 모든 
용액에서 검출되지 않았다.

물리적 스크래치를 가한 후의 용출 용액에 따른 유해 금속 용출량은 스크래치를 가하기 전보다 모든 용액에서 전반적으로 증가하는 것으로 조사되었다. 특히, $0.5 \%$ citric acid 용액에서는 스테인레스와 경질알루미늄 재질 코펠에 서 카드뮴이 용출되는 것으로 나타났다.

용출 시간에 따른 유해 금속 용출량 변화를 살펴보면, 증류수에서는 경질알루미늄, 연질알루미늄 재질 코펠과 불 소수지 코팅 불판의 알루미늄 용출량이 증가하였다. $0.5 \%$ citric acid 용액에서는 스테인레스, 경질알루미늄, 연질알루 미늄 재질 코펠의 니켈과 알루미늄 용출량이 증가하였고, 불소수지 코팅 불판은 납, 비소, 알루미늄 용출량이 증가하 였다. $1 \% \mathrm{NaCl}$ 용액에서는 스테인레스, 경질알루미늄 재질 코펠과 불소수지 코팅 불판의 비소 용출량이 증가하였고, 연질알루미늄 재질 코펠의 비소와 알루미늄 용출량이 증가 하였다.

\section{References}

1. Wernick S, Pinner R, Sheasby PG (1987) The Surface Treatment and Finishing of Aluminium and its Alloys. Vol. I, $5^{\text {th }}$ Ed, Finishing Publications Ltd, UK, p 1-50

2. Maynard RL (2001) The Merck Index, Merck \& CO INC, White House Station, NJ, USA, p 60, 136, 272, 967, 1165

3. Scncar J, Stibilj V, Milacic R (2004) Determination of aluminium in Slovenian foodstuffs and its leachability from aluminium-cookware. Food Chem, 85, 151-157

4. Gunnar FN, Bruce AF, Monica N, Lars TF (2007) Aluminium Handbook on the Toxicology of Metals. $3^{\text {rd }}$ Ed, Academic Press, Burlington, VT, USA, p 339-352

5. Gramiccioni L, Ingrao G, Milana MR, Santaroni $P$,
Tomassi G (1996) Aluminium levels in Italian diets and in selected foods from aluminium utensils. Food Addit Contam, 13, 767-774

6. Kamerud KL, Hobbie KA, Anderson KA (2013) Stainless steel leaches nickel and chromium into food during cooking. J Agric Foods Chem, 61, 9495-9501

7. World Health Organization. http://www.who.int /mediacentre/factsheets/en/ (accessed July 2017)

8. Croghan CW, Park NC, Egeghy PP (2003) Methods of dealing with values below the limit of detection using SAS. EPA Science Inventory

9. Kwon JW (2009) Definition and application of detection and quantification limits. Korean J Environ Agric, April 85-102

10. Choi JC, Park SJ, Goh HA, Lee JY, Eom MO, Kim MH (2014) A study on migration of heavy metals from kitchen utensils including glassware, ceramics, enamel, earthen and plastics. J Food Hyg Saf, 29, 334-339

11. Lee KH, Kwon KS, Jeon DH, Choi BH, Lee SH, Lee CW (1999) Migration mechanism of hazard elements from brass kitchenwares. J Korea Soc Packag Sci Technol, 5, 24-30

12. Lim JG (2005) The monitoring of harmful elements on food packaging (I)-Metallic kitchenware, Biodegradability disposable package. Report of Korea Environment \& Merchandise Testing Institute, 1470002069, 15-76

13. Kim MS, Cho TH, Kim CK, Kim HS, Shin GY, Kim JH, Jung K (2014) Measurement of hazardous metals migrated from cooking utensils for camping. Report of Seoul Institute Health Environment, 29-36

14. Lee SH, Jung KJ, Lee YK, Sung JH, Eom MO, Lee YJ, Lim JG (2007) Monitoring of lead and antimony in metallic kitchenware. J Food Hyg Saf, 22, 52-56 